\title{
Rancang Bangun Alat Pemilah Barang Berdasarkan Warna Dan Berat
}

\author{
Muhamad Maulana Yusuf ${ }^{1)}$ Mardiono $^{2)}$ dan Sri Wiji Lestari ${ }^{3)}$ \\ Program Studi Teknik Elektro FTI Universitas Jayabaya. \\ Jl. Raya Bogor KM 28,8 Cimanggis-Jakarta Timur \\ Corresponding author : sriwijilestari@ftijayabaya.ac.id
}

\begin{abstract}
Sorting things is usually done in the industry. Sorting items can be done by grouping the color and weight of the item. Some sorting of goods in the industry is still done manually by using human power, but the speed and accuracy are not reliable for the industry, so automation with tools is needed. This study designed a tool that can sort items by color and weight. The color sorter uses a TCS3200 sensor, and a heavy sorter uses a loadcell sensor. The steps taken are making an ultrasonic sensor setting program to read the presence or absence of objects on conveyors, programming and algorithms using Arduino for TCS3200 sensor programs as input for servo motors, and loadcell programs.
\end{abstract}

\begin{abstract}
Abstrak
Pemilahan barang jamak dilakukan di industri. Pemilahan barang dapat dilakukan dengan mengelompokkan warna dan berat barang. Beberapa pemilahan barang pada industri masih dilakukan dengan secara manual menggunakan tenaga manusia, namun kecepatan dan keakuratannya tidak handal untuk industri, maka diperlukan otomatisasi dengan alat. Penelitian ini merancang alat yang dapat melakukan Pemilahan barang berdasarkan warna dan berat. Alat pemilah warna menggunakan sensor TCS3200, dan penyortir berat menggunakan sensor loadcell. Langkah yang dilakukan adalah pembuatan program pengaturan sensor ultrasonik untuk membaca ada tidaknya benda pada konveyor, pemrograman dan algoritma menggunakan Arduino untuk program sensor TCS3200 sebagai inputan untuk motor servo, dan program loadcell.
\end{abstract}

Keywords: Item sorter, TCS3200 sensor, Loadcell, Ultrasonic sensor, Arduino, Servo moto 


\section{Pendahuluan}

Pemilahan barang jamak dilakukan di industri. Pemilahan barang dapat dilakukan dengan mengelompokkan jenis, warna, berat atau bentuk barang. Pemilahan dapat dilakukan dengan secara manual menggunakan tenaga manusia, sistem barcode, ataupun otomatisasi dengan mesin. Beberapa Pemilahan barang pada industri masih dilakukan dengan secara manual menggunakan tenaga manusia, namun kecepatan dan keakuratannya tidak handal untuk industri, maka diperlukan otomatisasi dengan alat.

Sistem pemilahan berdasarkan warna merupakan hal yang dapat dikembangkan dengan berbagai metode. Pendeteksian warna suatu benda dapat dilakukan menggunakan alat yang bisa menangkap pantulan cahaya dan menklasifikasikan warna yang ditangkap. Pada penelitian [1] pemilah barang menggunakan sensor warna TCS230 untuk mendeteksi warna dan digunakan PLC (Progammable Logic Control) sebagai sistem penggeraknya. Warna yang dideteksi yaitu warna hijau, merah, dan biru. Pada Penelitian [2] telah dibuat alat pemilah yang dapat memilah barang dengan warna merah, hijau, biru, hitam, dan putih. Hasil pengujian menunjukkan bahwa warna objek dapat diidentifikasi oleh sensor warna dengan kisaran warna yang ditentukan dan mengaktifkan motor servo tertentu.

Penyortiran berdasarkan berat merupakan hal yang dapat dikembangkan dengan berbagai metode. Penelitian [3] pengujian pada proses sortir menunjukkan ketika terdapat barang dengan berat yang tidak sesuai dengan keinginan pengguna, motor servo aktif. Penelitian [4] memperoleh hasil penyortiran menggunakan sensor loadcell, tingkat akurasi yang di miliki \pm 0,05 dalam skala satuan kilogram $(\mathrm{Kg})$.

Dari penelitian-penelitian yang dijelaskan sebelumnya, penelitian ini menggabungkan penelitian yang telah ada yaitu merancang alat yang dapat melakukan Pemilahan barang berdasarkan warna dan berat.

\section{Teori}

Sensor TCS3200 merupakan sensor warna yang bekerja dengan cara membaca nilai intensitas cahaya yang dipancarkan oleh led super bright terhadap objek, pembacaan nilai intensitas cahaya tersebut dilakukan melalui matrik 8x8 photodioda, dimana 64 photo dioda tersebut dibagi menjadi 4 kelompok pembaca warna, setiap warna yang disinari led akan memantulkan sinar led menuju photodioda, pantulan sinar tersebut memiliki panjang gelombang yang berbeda - beda tergantung pada warna objek yang terdeteksi. Hal ini yang membuat sensor warna TCS3200 dapat membaca beberapa macam warna [5]. Untuk menyortir berat benda dapat digunakan sensor loadcell. Sensor loadcell umumnya digunakan sebagai komponen utama pada sistem timbangan digital dan dapat diaplikasikan pada jembatan timbangan yang berfungsi untuk menimbang berat. Pengukuran yang dilakukan oleh loadcell menggunakan prinsip tekanan [6]. Kemudian data diterima oleh sensor warna kemudian dikirimkan ke mikrokontrol. Mikrokontrol ini di gunakan untuk mengatur motor memilah barang sesuai warna ke tempat penampungan yang berbeda. Jenis motor yang digunakan adalah motor servo yang merupakan perangkat yang terdiri dari motor DC, serangkaian gear, rangkaian control dan potensiometer. Serangkaian gear yang melekat pada poros motor DC akan memperlambat putaran poros dan meningkatkan torsi motor servo, sedangkan potensiometer dengan perubahan resistansinya saat motor berputar berfungsi sebagai penentu batas posisi putaran poros motor servo. Penggunaan sistem kontrol loop tertutup pada motor servo berguna untuk mengontrol gerakan dan posisi akhir dari poros motor servo [7]. 


\section{Perancangan Alat}

Pada pembuatan Rancang Bangun Alat pemilah warna menggunakan sensor TCS3200 dan untuk berat menggunakan sensor loadcell. ini dibagi menjadi 2 bagian yaitu perancangan hardware dan perancangan software

Perancangan Hardware

Deskripsi Alat

Deskripsi alat yang akan diuji meliputi:

Nama Alat : Rancang Bangun Alat Pemilah Barang Berdasarkan Warna Dan Berat

Fungsi Sistem : Memilah barang berdasarkan warna dan berat secara otomatis

Spesifikasi Alat

Dimensi $\quad: 55 \mathrm{~cm} \mathrm{X} 50 \mathrm{~cm} \mathrm{X} 60 \mathrm{~cm}$

Hasil Output : $5 \mathrm{~V}$

\subsection{Cara Kerja Alat}

Barang turun secara acak dari wadah, pada saat barang turun maka motor DC mendorong barang menuju konveyer secara satu per satu, pada saat barang melewati sensor ultrasonik maka sensor ultrasonik akan menghitung objek yang terdeteksi, setelah itu loadcell akan mendeteksi berat objek, selanjutnya TCS3200 RGB akan mendeteksi warna pada barang yang melewatinya, jika barang sudah terdeteksi maka motor servo akan menyesuaikan jalur sesuai dengan data warna yang diterima, dan barang akan masuk kedalam kotak sesuai warna benda.

Desain alat

1. Bentuk Fisik

Ukuran Prototipe $\quad: 55 \mathrm{~cm}$ x $50 \mathrm{~cm}$ x $60 \mathrm{~cm}$

Berat $\quad: 5 \mathrm{Kg}$

Bahan :Aluminium, Plat dan kayu

2. Tegangan catu daya sistem $: 220 \mathrm{~V}$

3. Arus input sistem :3 A

4. Sensor

Jenis Sensor

:Sensor TCS3200

Tegangan input $\quad: 5 \mathrm{~V}$

5. Motor servo

Berat :55 gr

Torsi $\quad: 10 \mathrm{~kg} / \mathrm{cm}$

Dimensi $\quad: 40.7 \times 19.7 \times 42.9 \mathrm{~mm}$

Kecepatan :0.20sec/60degree

6. Mikrokontroller

Jenis Mikrokontroller : Arduino Mega

Tegangan :5VDC

Operating Voltage $\quad: 5 \mathrm{~V}$

Input Voltage : $7-12 \mathrm{~V}$

Display

Jenis Display $\quad$ : Laptop Hp

Tegangan $: 220 \mathrm{~V}$

Desain alat dapat dilihat pada Gambar 1 dan 2. 


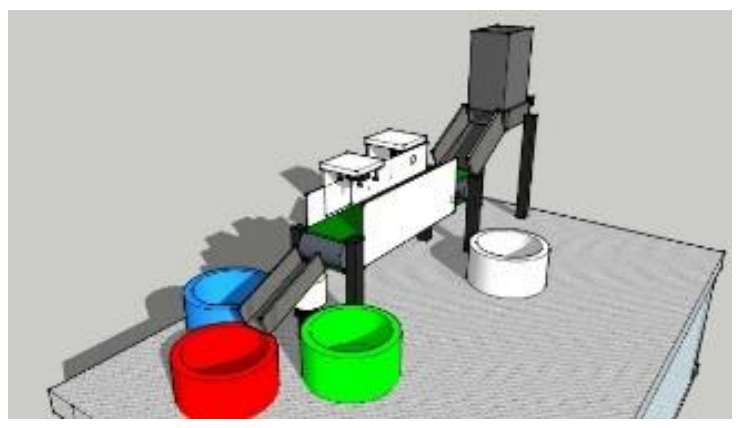

Gambar 1. Disain Alat Tampak Depan

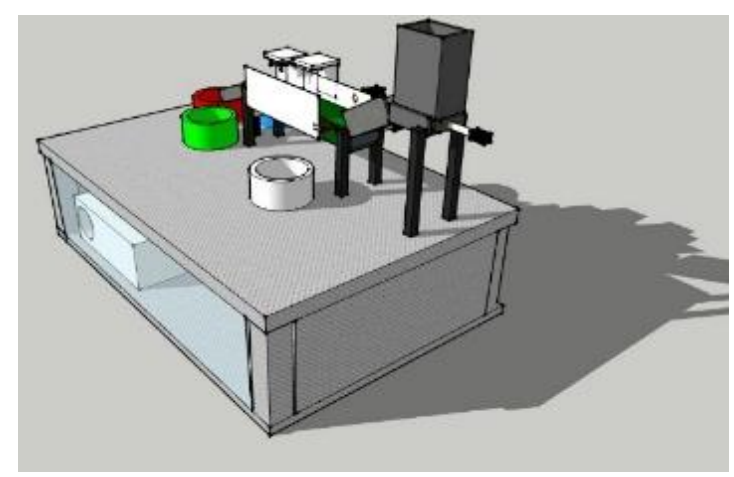

Gambar 2. Disain Alat Tampak Samping

\subsection{Perancangan Software}

Diawali dengan pembuatan diagram sistem pemilah barang berdasarkan warna dan berat yang ditunjukan pada Gambar 3.

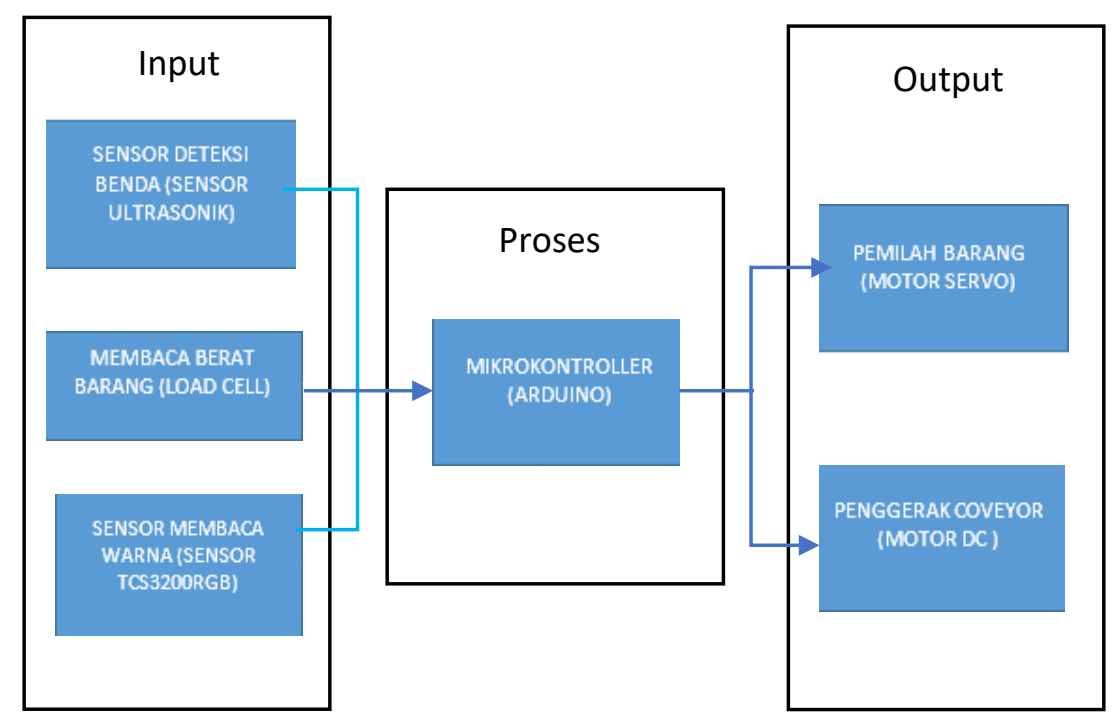

Gambar 3. Blok Diagram 
Kontroler yang digunakan pada alat ini adalah mikrokontroler Atmega256 dengan board Arduino Mega. Pemrograman dilakukan pada mikrokontroler bertujuan untuk mengolah data yang diberikan oleh sensor TCS3200. Selain itu mikrokontroler juga akan mengirimkan data pada motor servo untuk menentukan arah pengumpan, agar objek benda akan jatuh pada penampungan sesuai dengan warna yang telah dideteksi oleh sensor TCS3200.

Algoritma program penerimaan data dari sensor TCS3200 dan program utama pada Arduino mega dapat dilihat pada Gambar 4.

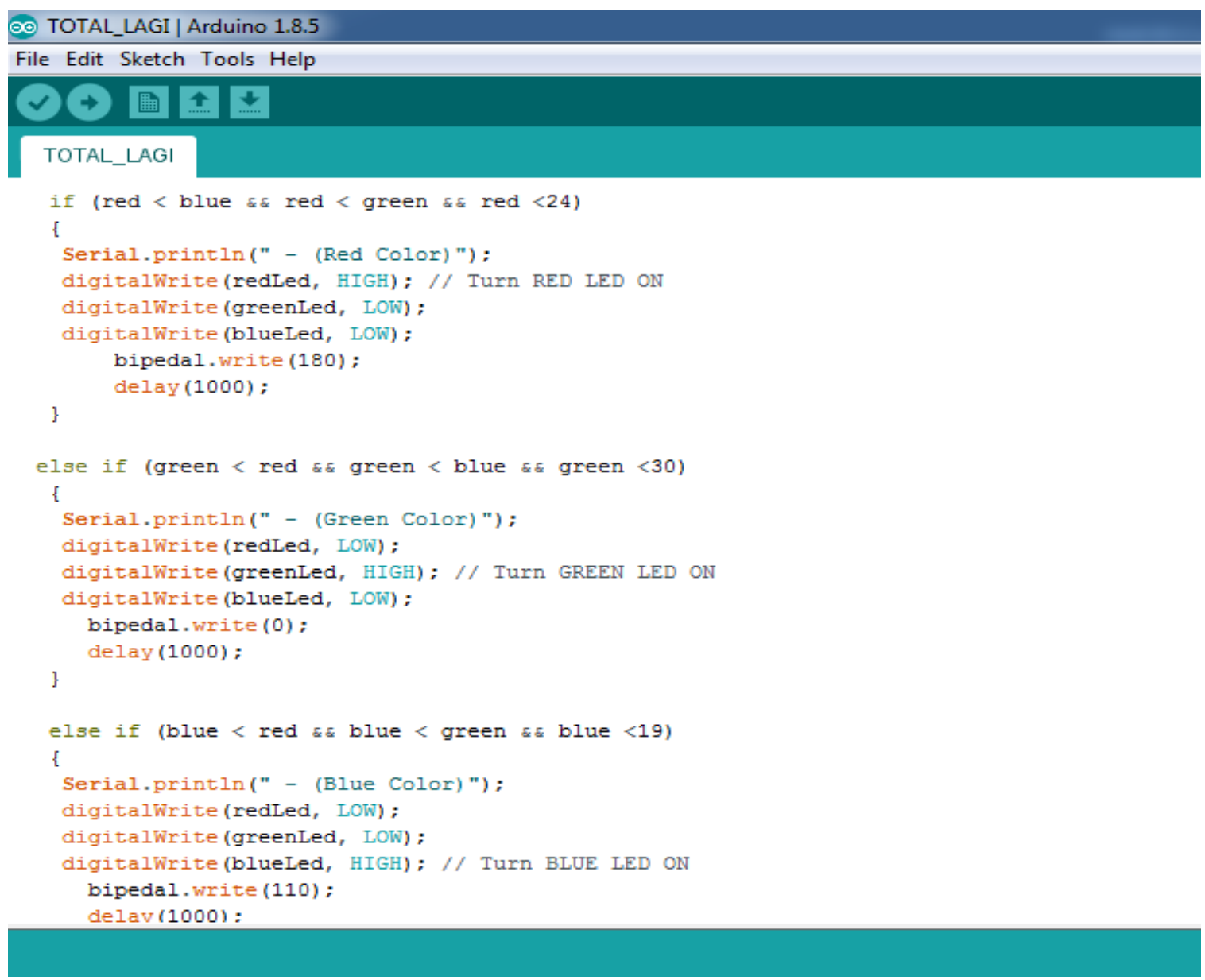

Gambar 4. Pemrograman Arduino

Dari flowchart pada Gambar 5, dapat terlihat cara kerja sistem. Kemudian dari flowchart tersebut dikonversikan menjadi sebuah program bahasa $\mathrm{C}$ Arduino untuk dimasukkan ke dalam mikrokontroler Arduino dengan bantuan software Arduino.

Jika benda memiliki berat kurang dari atau sama dengan 25 gram maka terdeteksi kecil atau tidak memenuhi standar, maka benda tidak akan dipergunakan. Jika benda memiliki berat lebih dari 25 gram maka akan bergerak melalui sensor pemilah warna. Jika warna pada benda terdeteksi merah maka motor servo bergerak ke $180^{\circ}$. Jika warna pada benda terdeteksi hijau maka motor servo bergerak ke $0^{\circ}$. Jika warna pada benda terdeteksi biru motor servo bergerak ke $90^{\circ}$. Benda akan jatuh ke penampungan sesuai dengan warnanya. 
Jurnal Teknologi, Tahun 2019, Volume 6, Edisi 2

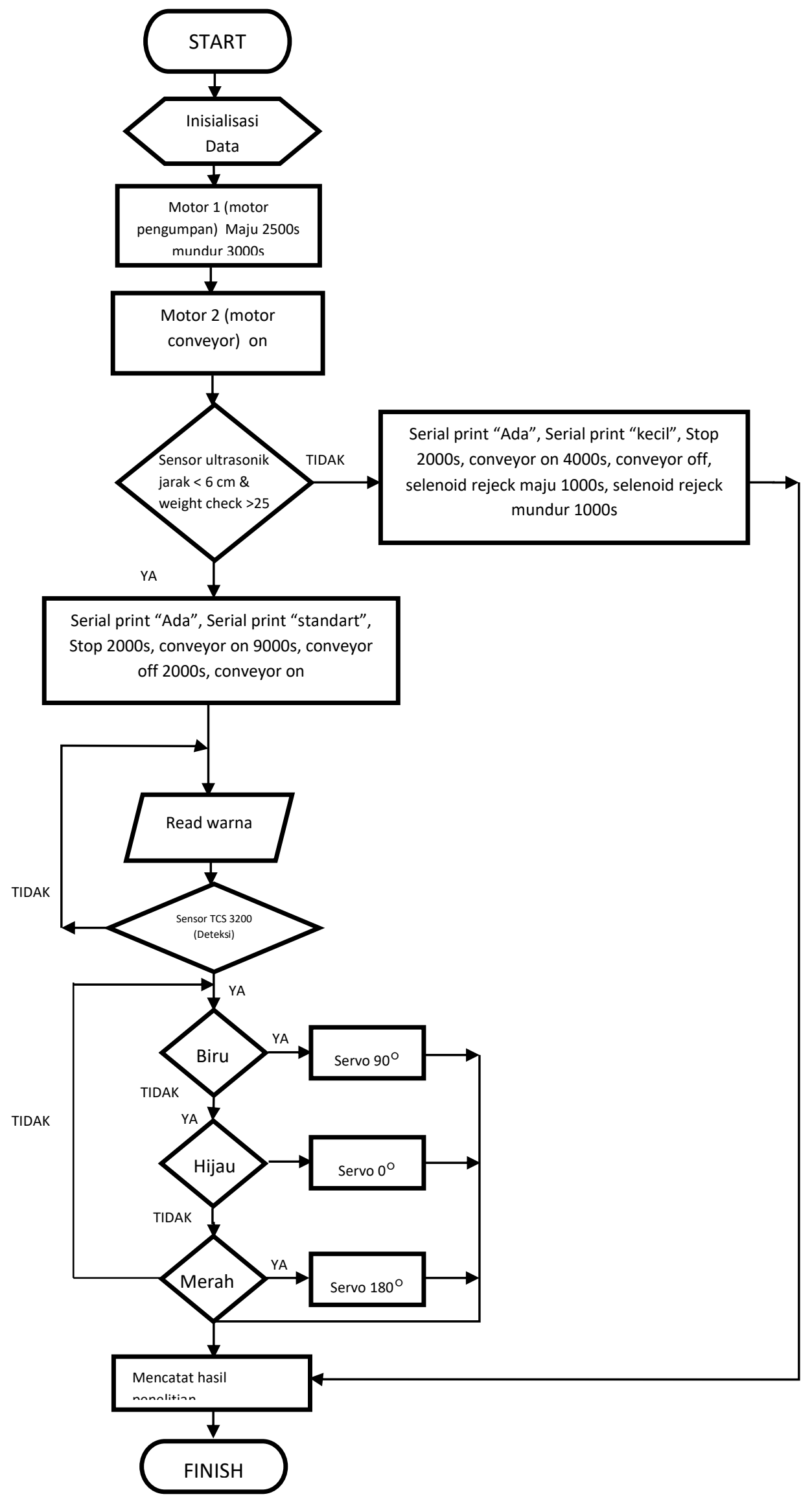

Gambar 5. Flowchart Pemrograman Arduino 


\section{Hasil dan Pembahasan}

\subsection{Tahapan Pengujian}

Pengujian akan dilakukan dalam 4 tahap:

1 Pengujian sensor ultrasonic dengan tujuan untuk mendeteksi keberadaan objek $<6 \mathrm{~cm}$

2 Pengujian loadcell dengan tujuan untuk mendeteksi berat objek $>25$ gram

3 Pengujian sensor warna TCS3200 dengan tujuan untuk mendeteksi warna objek

4 Pengujian perancangan pemrograman untuk menggerakkan motor servo pada alat

\subsection{Pengujian sensor Ultrasonik}

Pengujian sensor ultrasonic dilakukan dengan mengatur jarak objek dengan sensor, kemudian menguji kepekaan sensor dengan motor konveyor terhadap objek benda yang akan dideteksi keberadaannya.

Prosedur Pengujian

1 Mempersiapkan alat dan bahan yang digunakan, sesuai daftar alat dan bahan pengujian yang dapat dilihat pada Tabel 1.

2 Mengunggah program yang sudah dibuat dalam pemrograman arduino.

3 Meletakkan objek benda tepat di bawah sensor Ultrasonik.

4 Mengukur jarak benda yang terbaca dan yang tidak terbaca oleh sensor.

Tabel 1. Daftar Alat Dan Bahan Pengujian Sensor Infrared

\begin{tabular}{|c|c|c|c|}
\hline No & Nama alat/bahan & Tipe/ merk & Fungsi \\
\hline 1 & Laptop & $\mathrm{Hp}$ & $\begin{array}{l}\text { Mengunggah program pada arduino dan } \\
\text { manampilkan nilai pengukuran jarak pada serial } \\
\text { monitor }\end{array}$ \\
\hline 2 & Arduino & Mega 2560 & Mengolah data hasil pembacaan sensor Infrared \\
\hline 3 & Sensor Ultrasonik & - & Mendeteksi benda objek \\
\hline 4 & Kayu (balok) & - & Sebagai objek yang diukur \\
\hline 5 & Penggaris & - & Mengukur jarak secara manual \\
\hline
\end{tabular}
2.

Hasil pengujian jarak pembaca sensor ultrasonic terhadap objek benda terlihat pada tabel

Tabel 2. Data Hasil Pengujian Sensor Ultrasonik

\begin{tabular}{ccccc}
\hline \multirow{2}{*}{ No } & \multicolumn{3}{c}{ Ultrasonik } & \multirow{2}{*}{$\begin{array}{c}\text { Kesalahan } \\
\text { pembacaan }(\%)\end{array}$} \\
\cline { 2 - 4 } & Pembacaan sensor & penggaris & Keterangan benda & 6,16 \\
1 & 3,41 & 3,2 & ada & 6,43 \\
2 & 3,42 & 3,2 & ada & 3,11 \\
3 & 5,78 & 5,6 & tidak ada & 0,88 \\
4 & 5,65 & 5,6 & tidak ada & 3,11 \\
5 & 5,78 & 5,6 & tidak ada & 2,78 \\
6 & 5,76 & 5,6 & tidak ada & 2,78 \\
7 & 5,76 & 5,6 & tidak ada & 2,78 \\
8 & 5,76 & 5,6 & tidak ada & 0,88 \\
9 & 5,65 & 5,6 & tidak ada & 2,78 \\
10 & 5,76 & 5,6 & tidak ada & 5,18 \\
\hline \multicolumn{4}{c}{} \\
\hline
\end{tabular}


Berdasarkan data hasil pengujian Tabel 2, terlihat bahwa benda terdeteksi saat konveyor berjalan sensor membaca jarak 3,2 cm dan tidak terdeteksi saat sensor membaca 5,6 cm.

\subsection{Pengujian loadcell}

Pengujian sensor loadcell menggunakan timbangan digital, untuk memperoleh data perbandingan akurasi antara loadcell dan timbangan digital.

Prosedur Pengujian

1 Mempersiapkan alat dan bahan yang digunakan, sesuai daftar alat dan bahan pengujian yang dapat dilihat pada Tabel 3 .

2 Mengunggah program yang sudah dibuat arduino.

3 Meletakkan objek benda tepat di bawah sensor loadcell

4 Melakukan pengukuran dengan serial monitor arduino

5 Melakukan perbandingan antara timbangan digital dengan loadcell

Tabel 3. Daftar Alat Dan Bahan Pengujian Loadcell

\begin{tabular}{clcl}
\hline No & $\begin{array}{c}\text { Nama } \\
\text { alat/bahan }\end{array}$ & Tipe/ merk & \multicolumn{1}{c}{ Fungsi } \\
\hline 1 & Laptop & Hp & $\begin{array}{l}\text { Mengunggah program pada arduino dan } \\
\text { manampilkan nilai pengukuran jarak pada } \\
\text { serial monitor }\end{array}$ \\
2 & Arduino & Mega 2560 & Mengolah data hasil pembacaan sensor Infrared \\
3 & Sensor loadcell & - & Mendeteksi benda objek \\
4 & Kayu (balok) & - & Sebagai objek yang diukur \\
5 & $\begin{array}{l}\text { Timbangan } \\
\text { digital }\end{array}$ & - & Mengukur berat secara manual \\
\hline
\end{tabular}

Berdasarkan data hasil pengujian, jika ada benda yang terdeteksi oleh sensor loadcell maka nilai akan terbaca dengan satuan gram dan memiliki selisih dengan timbangan digital. Data hasil pengujian dapat dilihat pada Tabel 4.

Tabel 4. Data Hasil Pengujian Sensor Loadcell

\begin{tabular}{|c|c|c|c|c|}
\hline \multirow{2}{*}{ No } & \multicolumn{2}{|c|}{ hasil pengukuran (gram) } & \multirow{2}{*}{ Selisih (gram) } & \multirow{2}{*}{ Kesalahan (\%) } \\
\hline & timbangan digital & sensor loadcell & & \\
\hline 1 & 38,33 & 32,49 & 5,84 & 15,24 \\
\hline 2 & 39,44 & 35,26 & 4,18 & 10,60 \\
\hline 3 & 37,23 & 37,01 & 0,22 & 0,60 \\
\hline 4 & 40,36 & 38,61 & 1,75 & 4,33 \\
\hline 5 & 39,92 & 31,96 & 7,96 & 19,94 \\
\hline 6 & 19,22 & 11,21 & 8,01 & 41,68 \\
\hline 7 & 19,18 & 11,48 & 7,70 & 40,15 \\
\hline \multicolumn{3}{|c|}{ Rata - Rata } & 8,92 & 33,13 \\
\hline
\end{tabular}

Berdasarkan data hasil pengujian, Tabel 4. menunjukan bahwa sensor loadcell memiliki selisih dengan rata - rata 8,92 gram dan memiliki rata - rata kesalahan 33,13\%. Namun 
untuk objek dengan berat diatas 25 gram rata rata kesalahan berada dibawah $20 \%$, yaitu $10,142 \%$.

\subsection{Pengujian sensor warna TCS3200}

Pengujian sensor warna TCS3200 dilakukan dengan cara mengamati nilai RGB yang terbaca pada serial monitor software Arduino IDE.

Prosedur pengujian sensor warna TCS3200

1 Mempersiapkan alat dan bahan yang digunakan, sesuai daftar alat dan bahan pengujian yang dapat dilihat pada Tabel 5.

2 Mengunggah program yang sudah dibuat dalam pemrograman arduino.

3 Menghadapkan sensor warna kepada palet warna.

4 Mengukur jarak antara sensor warna dengan palet warna.

5 Mengamati nilai RGB yang ditampilkan pada serial monitor software Arduino IDE.

6 Mencatat hasil pengamatan nilai RGB

Tabel 5. Daftar Alat Dan Bahan Pengujian Sensor Warna TCS3200

\begin{tabular}{|c|c|c|c|}
\hline No & $\begin{array}{l}\text { Nama } \\
\text { alat/bahan }\end{array}$ & \multicolumn{2}{|c|}{ Tipe/ merk $\quad$ Fungsi } \\
\hline 1 & Laptop & $\mathrm{Hp}$ & $\begin{array}{l}\text { Mengunggah program pada arduino } \\
\text { dan manampilkan nilai pengukuran } \\
\text { jarak pada serial monitor }\end{array}$ \\
\hline 2 & Arduino & Mega 2560 & $\begin{array}{l}\text { Mengolah data hasil pembacaan } \\
\text { sensor TCS3200 }\end{array}$ \\
\hline 3 & Sensor warna & TCS3200 & Mendeteksi nilai RGB palet warna \\
\hline 4 & Palet & - & $\begin{array}{l}\text { Objek warna yang diuji berbentuk } \\
\text { balok }\end{array}$ \\
\hline
\end{tabular}

Hasil pengujian sensor warna TCS3200 terhadap objek benda yang akan dideteksi warnanya terlihat pada Tabel 6, Tabel 7 dan Tabel 8. Objek yang dipergunakan dalam pengujian memiliki warna merah, hijau dan biru dengan jarak benda ke sensor ditentukan 1 $\mathrm{cm}$. Warna yang terdeteksi terlihat memiliki intensitas warna yang terkecil.

Tabel 6. Data Hasil Pengujian Objek Hijau

\begin{tabular}{ccccc}
\hline No & Intensitas R & Intensitas G & Intensitas B & Keterangan \\
\hline 1 & 48 & 29 & 40 & Hijau \\
2 & 45 & 29 & 39 & Hijau \\
3 & 47 & 28 & 38 & Hijau \\
4 & 40 & 27 & 40 & Hijau \\
5 & 45 & 27 & 39 & Hijau \\
6 & 43 & 22 & 39 & Hijau \\
7 & 47 & 28 & 38 & Hijau \\
8 & 40 & 27 & 40 & Hijau \\
9 & 45 & 29 & 39 & Hijau \\
10 & 45 & 29 & 39 & Hijau \\
\hline
\end{tabular}


Tabel 7. Data Hasil Pengujian Objek Biru

\begin{tabular}{ccccc}
\hline No & Intensitas R & Intensitas G & Intensitas B & Keterangan \\
\hline 1 & 46 & 27 & 17 & Biru \\
2 & 44 & 27 & 17 & Biru \\
3 & 46 & 25 & 17 & Biru \\
4 & 45 & 26 & 16 & Biru \\
5 & 45 & 27 & 17 & Biru \\
6 & 47 & 27 & 17 & Biru \\
7 & 49 & 26 & 17 & Biru \\
8 & 46 & 27 & 17 & Biru \\
9 & 50 & 28 & 17 & Biru \\
10 & 46 & 27 & 17 & Biru \\
\hline
\end{tabular}

Tabel 8. Data Hasil Pengujian Objek Merah

\begin{tabular}{ccccc}
\hline No & Intensitas R & Intensitas G & Intensitas B & Keterangan \\
\hline 1 & 25 & 71 & 52 & Merah \\
2 & 25 & 65 & 54 & Merah \\
3 & 25 & 72 & 54 & Merah \\
4 & 25 & 66 & 58 & Merah \\
5 & 19 & 76 & 56 & Merah \\
6 & 19 & 68 & 51 & Merah \\
7 & 25 & 65 & 54 & Merah \\
8 & 25 & 72 & 54 & Merah \\
9 & 25 & 66 & 58 & Merah \\
10 & 25 & 72 & 54 & Merah \\
\hline
\end{tabular}

Hasil pengujian pada Tabel 6, Tabel 7 dan Tabel 8, merupakan komposisi nilai RGB (Red, Green dan Blue) hasil keluaran sensor warna TCS3200. Terlihat bahwa hasil warna yang terbaca pada sensor adalah nilai komposisi RGB nilai intesitasnya paling kecil. Langkah mendeteksi warna, pertama mengaktifkan semua filter photodiede secara bergantian. Untuk mengaktifkan filter yang digunakan dapat diatur melalui logika pada pin S2 dan S3. Hal ini dilakukan untuk mengetahui nilai frekuensi ketika filter yang digunakan sesuai dengan warna yang dideteksi. Ketika sensor mendeteksi sebuah warna, maka mikrokontroler akan langsung menghitung periode pulsa yang dihasilkan oleh cahaya yang datang. Setelah periode pulsa didapatkan maka frekuensi dari output sensor dapat dihitung dengan persamaan.

Tabel 9. Memperlihatkan hasil Pengujian Alat terkait sensor ultrasonic dan sensor Warna TCS3200 terhadap benda dengan jarak objek 3,2 cm dari sensor ultrasonic. 
Tabel 9. Data Hasil Pengujian sensor ultrasonic dan sensor Warna TCS3200

\begin{tabular}{lllll}
\hline No & $\begin{array}{c}\text { Warna } \\
\text { Objek }\end{array}$ & ultrasonik & Tcs3200 & Keterangan \\
\hline 1 & Merah & Terdeteksi & Terbaca & Di awal sensor \\
2 & Biru & Terdeteksi & Terbaca & Di awal sensor \\
3 & Merah & Terdeteksi & Terbaca & Di awal sensor \\
4 & Merah & Terdeteksi & Terbaca & Di akhir sensor \\
5 & Hijau & Terdeteksi & Terbaca & Di akhir sensor \\
6 & Hijau & Tidak & Terbaca & Tidak Berhenti \\
7 & Biru & Terdeteksi & Terbaca & Di akhir sensor \\
8 & Biru & Terdeteksi & Terbaca & Di akhir sensor \\
9 & Merah & Terdeteksi & Terbaca & Di awal sensor \\
10 & Hijau & Terdeteksi & Terbaca & Di awal sensor \\
\hline
\end{tabular}

Hasil pengujian alat, kegagalan sensor ultrasonic yang didapat 10\% dari 10 kali percobaan dikarenakan karena sensor mendeteksi benda yang berjalan. Dan kesalahan yang didapatpun hanya tidak terbaca pada sensor ultrasonik, namun tetap terbaca pada sensor warna TCS3200. Hasil pengujian menunjukkan 5 benda sudah terdeteksi saat berada di posisi awal sensor dan 4 benda terdeteksi saat benda berada di akhir sensor.

\subsection{Pengujian perancangan pemrograman pada alat}

Pengujian dan analisa dilakukan untuk mengetahui apakah perancangan pemrograman pada alat pemilah barang berdasarkan warna bekerja sesuai yang direncanakan. Tujuan Pengujian untuk melihat apakah derajat motor servo dengan warna objek yang telah di deteksi sensor.

Prosedur pengujian

1 Mempersiapkan alat dan bahan yang digunakan, sesuai daftar alat dan bahan pengujian yang dapat dilihat pada Tabel 10.

2 Mengunggah program yang sudah dibuat ke arduino.

3 Memasang motor servo pada Arduino.

4 Menguji data hasil pengukuran dengan jalur bebas yang sudah didapat

Tabel 10. Alat Pengujian

\begin{tabular}{|c|c|c|c|}
\hline No. & Alat/Bahan & & Fungsi \\
\hline 1 & Sensor & TCS3200 & $\begin{array}{l}\text { Mendeteksi warna objek, } \\
\text { sebagai input untuk } \\
\text { menggerakan motor sevo }\end{array}$ \\
\hline 2 & LAPTOP & Hp & $\begin{array}{l}\text { Mengunggah program pada } \\
\text { arduino dan menampilkan nilai } \\
\text { pengukuran jarak pada serial } \\
\text { monitor }\end{array}$ \\
\hline 3 & Mikrokontroler & Arduino & $\begin{array}{l}\text { Sebagai kontroler dan } \\
\text { pemroses data }\end{array}$ \\
\hline 4 & Motor Servo & M995 & $\begin{array}{l}\text { Sebagai penggerak pengumpan } \\
\text { objek agar objek jatuh sesuai } \\
\text { dengan warna }\end{array}$ \\
\hline 5 & Multimeter & - & $\begin{array}{l}\text { Mengukur tegangan pada } \\
\text { motor DC }\end{array}$ \\
\hline
\end{tabular}


Hasil pengujian alat ini untuk melihat apakah derajat motor servo sesuai dengan warna objek yang telah di deteksi sensor warna dapat dilihat pada Tabel 11.

Tabel 11. Data Hasil Pengukuran

\begin{tabular}{cccccc}
\hline \multirow{2}{*}{ No } & \multicolumn{3}{c}{ SERVO } & Kesalahan $(\%)$ \\
\cline { 2 - 6 } & Derajat servo $\left(^{\circ}\right)$ & $\begin{array}{c}\text { Warna } \\
\text { Objek }\end{array}$ & $\begin{array}{c}\text { arah } \\
\text { penampung }\end{array}$ & $\begin{array}{c}\text { pada } \\
\text { busur }\left(^{(}\right)\end{array}$ \\
\hline 1 & 180 & Merah & kiri & 175 & 3 \\
2 & 0 & Hijau & kanan & 0 & 0 \\
3 & 0 & Hijau & kanan & 0 & 0 \\
4 & 180 & Merah & kiri & 175 & 3 \\
5 & 90 & Biru & tengah & 80 & 11 \\
6 & 180 & Merah & kiri & 175 & 3 \\
7 & diam & Biru & diam & - & 0 \\
8 & diam & Merah & diam & - & 0 \\
9 & 90 & Biru & tengah & 80 & 11 \\
10 & 0 & Hijau & kanan & 0 & 0 \\
\hline \multicolumn{7}{c}{ Rata - Rata kesalahan arah servo } \\
\hline \multicolumn{7}{c}{}
\end{tabular}

Hasil pengujian alat menunjukkan motor servo bergerak sesuai dengan warns benda yang terdeteksi oleh sensor warna. Terdapat kegagalan sebesar $20 \%$, mesin servo tidak bergerak, namun benda tetap terdeteksi warnanya oleh sensor TCS3200. Hasil pengujian sensor dan alat terangkum dalam table 12 .

Tabel 12. Rangkuman Hasil Pengujian Alat

\begin{tabular}{clcl}
\hline No. & \multicolumn{1}{c}{ Jenis } & Kesalahan $(\%)$ & \multicolumn{1}{c}{ Keterangan } \\
\hline 1 & Sensor Ultrasonik & 0 & Dengan jarak objek $\leq 3,2 \mathrm{~cm}$ \\
2 & Sensor TCS3200 & 0 & Dengan jarak objek $1 \mathrm{~cm}$ \\
3 & Derajat Servo & 4,55 & Ketepatan gerak servo \\
4 & Loadcell & 40,915 & Berat objek $<25$ gr \\
5 & Loadcell & 10,142 & Berat objek $>25 \mathrm{gr}$ \\
\hline
\end{tabular}

\section{Kesimpulan}

Kesimpulan yang dapat diambil dari hasil penelitian adalah Sensor Ultrasonik mendeteksi objek yang melewati dengan jarak benda kurang dari $3,3 \mathrm{~cm}$, Sensor loadcell dapat mendeteksi benda dengan berat lebih dari 25 gr dengan kesalahan 10,146 \%, Sensor TCS3200 dapat mendeteksi benda yang melewatinya berwarna Merah, hijau atau biru pada jarak $1 \mathrm{~cm}$, Motor servo memiliki kegagalan 20\% dengan ketidak-tepatan derajat servo memiliki kesalahan sebesar 4,55\% .

\section{Ucapan Terimakasih}

Terimakasih kepada Fakultas Teknologi Industri Universitas Jayabaya yang membiayai penelitian ini melalui dana penelitian dosen FTI UJ Semester Ganjil tahun anggaran $2018 / 2019$. 


\section{DAFTAR PUSTAKA}

[1]. W. Euis, H. Witarsa, M. Verdian, and D. Yuniarti, "Prototipe Penyortir Barang Berdasarkan Warna , Bentuk Dan Tinggi Berbasis Programmable Logic Controller ( Plc ) Dengan Penggerak Sistem Pneumatic", Mikrotiga, Vol 1 No. 2, 8 - 13. 2014.

[2]. Ike Sari 1, M., Handayani, R., Siregar S., dan Isnu, B., "Pemilah Benda Berdasarkan Warna Menggunakan Sensor Warna TCS3200”, TELKA, Vol.4, No.2, November 2018.

[3]. Rukmana, I., Cipta, A. dan Abdul, R., “Aplikasi Sensor Loadcell pada Purwarupa Sistem Sortir Barang", IJEIS, Vol 4, No 1, 2014.

[4]. Wahyudi W., Rahman A., dan Nawawi, M., "Perbandingan Nilai Ukur Sensor Loadcell pada Alat Penyortir Buah Otomatis terhadap Timbangan Manual”, ELKOMIKA, Vol. 5, No. 2, 2017.

[5]. Kadir, Abdul, "Arduino Dan Sensor, Tuntunan Praktis Mempelajari Penggunaan Sensor Untuk Aneka Proyek Elektronika Berbasis Arduino+cd”, Andi Publisher, Jogyakarta, 2018.

[6] Setiawan, I., "Buku Ajar Sensor dan Tranduser”, FT Undip, Semarang, 2009.

[7] Lutfi, Muchtar, "Pengoperasian Motor Servo", Kemendikbud, Jakarta, 2017. 